\title{
Pengaruh Perceived Value terhadap Behavioral Loyalty melalui Customer Satisfaction sebagai Variabel Pemediasi pada Pengguna Credit Card Co-Branding Bank Aceh
}

\author{
Dhian Wahyuni \\ Sekolah Tinggi Ilmu Ekonomi Sabang, Banda Aceh \\ e-mail:dhian@stiesabang.ac.id \\ Ihsanuddin \\ AMIK Indonesia \\ e-mail:ihsan.amik@gmail.com
}

\begin{abstract}
The main objectives of the study is to analyze the effect of perceived value on customer satisfaction and its impact on the behavioral loyalty of users cobranding credit card of Bank Aceh Syariah. The research sample are 250 customers taken by random sampling. Data collection uses a questionnaire, and then the data is analyzed by statistical means of path analysis. The study found that perceived value has a positive and significant effect on customer satisfaction and behavioral loyalty. Customer satisfaction also has a positive and significant effect on behavioral loyalty. The existence of customer satisfaction strengthens the influence of perceived value on behavioral loyalty. The effect of mediating customer satisfaction in mediating the functional relationship between the two variables is partial mediation.
\end{abstract}

Keywords: Behavioral Loyalty, Customer Satisfaction, Perceived Value, Path Analysis.

\section{PENDAHULUAN}

Eksistensi lembaga keuangan bank sangat penting untuk mendukung kegiatan ekonomi masyarakat. Peran institusi tersebut menjalankan fungsi intermediasi keuangan di antaranya dalam bentuk penyaluran kredit atau pembiayaan diharapkan mampu memberi dampak positif bagi variabel makro ekonomi seperti peningkatan ketersediaan lapangan kerja, pertumbuhan ekonomi, penurunan ketimpangan pendapatan di masyarakat dan lain sebagainya. Apalagi kondisi paling ideal seiring dengan peningkatan kegiatan ekonomi adalah perbaikan distribusi pendapatan seiring pertumbuhan output dalam perekonomian (Amri \& Nazamudin, 2018). Peran bank sebagai perantara keuangan di masyarakat sangat berpeluang untuk dapat mewujudkan kondisi tersebut. Hal ini disebabkan bank tidak hanya melayani masyarakat yang kelebihan dana (nasabah simpanan), tetapi juga melayani kelompok masyarakat yang membutuhkan dana (nasabah kredit atau pembiayaan). Karena itu, upaya perbaikan layanan sangat penting bagi kedua kelompok nasabah tersebut.

Peningkatan kualitas pelayanan menjadi perhatian bagi setiap lembaga keuangan bank. Bank dengan kualitas pelayanan yang baik seharusnya berupaya melakukan inovasi yang memudahkan nasabahnya memanfaatkan layanan yang disediakan. Bank yang tidak mampu memberikan pelayanan terbaik, akan ditinggalkan nasabahnya. Kondisi tersebut tentunya tidak hanya berdampak pada citra bank tersebut, tetapi dapat berpengaruh pada kinerja bank secara keseluruhan. Apalagi bank pada dasarnya hanya sebagai lembaga 
perantara antara nasabah tabungan dan nasabah kredit atau pembiayaan (Amri et al., 2018).

Bank Aceh Syariah sebagai lembaga keuangan milik pemerintah daerah juga menyadari pelayanan nasabah sangat penting untuk perkembangan lembaga keuangan itu di masa yang akan datang. Apalagi bank tersebut harus bersaing dengan bank umum nasional yang mana juga memberikan layanan jasa keuangan. Ketika Bank Aceh tak mampu memberikan pelayanan sebagaimana halnya bank umum nasional, maka dikuatirkan sebagian nasabah akan lebih cenderung memanfaatkan layanan jasa bank lain selain Bank Aceh.

Guna meningkatkan kualitas pelayanannya, bank tersebut menggandeng Bank Mandiri menerbitkan kartu kredit cobranding. Co-branding merupakan strategi branding dengan cara memberikan dua merek terhadap suatu produk secara bersamaan. Strategi itu bertujuan untuk meningkatkan ekuitas merek dengan cara menggabungkan kekuatan merek-merek memiliki potensi untuk dapat dikolaborasikan. Tujuan bank penerbitan kartu kredit co-branding antara Bank Aceh Syariah dan Bank Mandiri adalah untuk memenuhi kebutuhan nasabah bank tersebut.

Hingga saat ini penggunaan kartu kredit co-branding Bank Aceh sudah familiar di sebagian besar nasabahnya. Penggunaan kartu tersebut terutama oleh nasabah perusahaan diharapkan dapat memberikan kemudahan dalam bertransaksi sehingga mereka benarbenar nyaman menjadi nasabah Bank Aceh Syariah. Kenyataannya, hasil survei awal yang peneliti lakukan melalui wawancara dengan sejumlah nasabah diperoleh informasi empiris bahwa perilaku mereka dalam menggunakan kartu kredit tersebut relatif berbeda. Ada di antara nasabah yang selalu menggunakan kartu kredit co-branding Bank Aceh sejak mereka tercatat sebagai pemilik kartu tersebut. Namun di sisi lain tidak sedikit di antara mereka yang selain menggunakan kartu kredit Bank Aceh juga memanfaatkan kartu kredit bank lain di dalam memenuhi kebutuhan mereka atas layanan perbankan.
Bahkan hasil survei awal juga mengungkapkan adanya nasabah yang sebelumnya telah memiliki kartu kredit Bank Aceh beralih menggunakan kartu kredit bank lain dengan sejumlah alasan. Fenomena ini menjadi bukti empiris awal tentang adanya persoalan loyalitas penggunaan kartu kredit bank tersebut.

Loyalitas yang dimaksudkan dalam kajian ini adalah behavioral loyalty. Behavioral loyalty merupakan loyalitas yang muncul karena adanya perubahan tingkatan harga, lokasi penjualan yang dinilai nyaman oleh konsumen, dan juga dapat disebabkan evaluasi konsumen terhadap harga produk (Neal, 2010). Loyalitas keperilakuan sering di anggap sebagai konsumen yang menekankan pentingnya runtutan pembelian, proporsi pembelian dan kemungkinan terjadinya pembelian (Darsono, 2014).

Loyalitas seseorang pengguna kartu kredit co-branding Bank Aceh tentunya dapat dipengaruhi oleh kepuasan yang diperolehnya dari penggunaan kartu kredit tersebut. Customer satisfaction sebagai perasaan positif secara keseluruhan tentang pelayanan yang diberikan oleh produsen (Yang \& Peterson, 2014). Adanya keterkaitan antara loyalty dengan customer satisfaction secara empiris juga dibuktikan oleh Khan dan Kadir (2011) serta Dehghan et al. (2015) bahwa kepuasan konsumen akan mempengaruhi loyalitas konsumen yang bersangkutan. Semakin baik customer satisfaction akan semakin tinggi loyalitas konsumen.

Selain itu, loyalty juga dapat dipengaruhi oleh perceived value. Customer perceived value adalah perbandingan dari hasil yang didapat konsumen dengan hasil produksi produsen. Konsep persamaan ini mengacu pada evaluasi konsumen terhadap apa yang adil, benar, atau pantas terhadap biaya yang dikeluarkan oleh konsumen. Jadi perceived value dilihat dari hasil evaluasi manfaat dan pengorbanan yang dilakukan atas sesuatu yang ditawarkan. Pengorbanan ini dapat berbentuk moneter dan non-moneter seperti waktu dan energi yang terpakai (Yang \& Peterson, 2014). Adanya keterkaitan antara perceived value dengan loyalty seperti 
ditemukan oleh Anuwichanont dan Mechinda (2016), Shanmugam et al. (2014), Asy'ari (2014), serta Picon-Berjoyo et al. (2016) bahwa perceived value tidak hanya berdampak pada customer satisfaction tetapi juga mempengaruhi loyalitas konsumen.

Hasil survei awal terhadap sejumlah pengguna kartu kredit co-branding Bank Aceh Syariah mengindikasikan kepuasan mereka dalam menggunakan kartu kredit tersebut relatif berbeda satu sama lain. Selain itu, perceived value (nilai yang mereka persepsikan) sehubungan dengan eksistensi kartu kredit tersebut juga relatif berbeda. Seperti dijelaskan sebelumnya, baik kepuasan maupun perceived value secara teoritis dan empiris bisa berpengaruh terhadap behavioral loyalty. Sehingga kajian mengenai keterkaita antara ketiga variabel tersebut dinilai penting sebagai dasar pertimbangan bank dalam meningkatkan loyalitas nasabah dalam menggunakan kartu kredit. Karena itu, penelitian ini bertujuan untuk menganalisis pengaruh perceived value terhadap behavioral loyalty pengguna kartu kredit tersebut dengan menggunakan customer satisfaction sebagai variabel pemediasi.

\section{Loyalitas}

Loyalitas dapat diartikan sebagai ketetapan hati untuk melakukan pembelian atau berlangganan produk atau jasa secara tetap di masa yang akan datang (Oliver, 2017). Selanjutnya Kotler dan Keller (2016) berpendapat bahwa loyalitas pelanggan identik dengan komitmen untuk berlangganan kembali produk atau jasa tertentu di masa yang akan datang, kendatipun terdapat pengaruh situasional akibat adanya usaha pemasaran yang memiliki potensi dapat mendorong perubahan perilaku pembeli.

Loyalitas berkaitan dengan alternatif pilihan yang dilakukan oleh konsumen untuk membeli barang dan jasa dengan merek tertentu dibandingkan dengan merek lainnya dalam kelompok produk yang sama (Giddens \& Hofmaan, 2012). Schiffman dan Kanuk (2014) menyatakan bahwa loyalitas dapat dilihat sebagai preferensi konsumen untuk membeli produk dan jasa dengan merek yang sama dalam katagori kelompok produk dan jasa tertentu. Namun demikian, terdapat perbedaan antara loyalitas konsumen dengan perilaku pembelian secara berulang-ulang. Perilaku pembelian yang berulang (repeat purchasing behavior) pada dasarnya adalah adalah tindakan pembelian secara berulangulang terhadap produk atau merek tertentu yang lebih cenderung terdorong oleh faktor kebiasaan. Sedangkan dalam kaitannya pada loyalitas konsumen, tindakan pembelian ulang terhadap produk dan jasa lebih ditentukan oleh kesetiaan merek sebagai diterminan utamanya.

\section{Behavioral Loyalty}

Behavioral loyalty atau loyalitas keperilakuan adalah loyalitas yang timbul akibat adanya perubahan harga (seperti harga yang lebih murah), perubahan lokasi/tempat memperoleh produk sehingga dianggap lebih nyaman bagi konsumen dan loyalitas yang disebabkan oleh adanya hasil evaluasi benefit oleh konsumen (Neal, 2010). Loyalitas itu bisa dipahami sebagai konsep yang memberi penekanan pada rentetan peristiwa pembelian, proporsi pembelian dan kemungkinan melakukan pembelian (Darsono, 2014).

Pendekatan keperilakuan memiliki asumsi bahwa pembelian yang dilakukan terhadap suatu merek tertentu dalam periode waktu tertentu merupakan sinyalemen penting yang mengindikasikan adanya loyalitas. Asy'ari (2014) memiliki pandangan bahwa loyalitas keperilakuan lebih mengarah pada pembelian secara berulang dan juga kemauan pelanggan untuk merekomendasikan produk kepada teman-teman mereka.

Behavioral loyalty dapat dibentuk oleh sejumlah faktor. Faktor-faktor dimaksud terkait dengan sejumlah faktor yang dapat mempengaruhi loyalitas secara umum seperti customer satisfaction dan perceived value. Adanya pengaruh beberapa faktor tersebut terhadap behavioral loyalty juga diperkuat oleh sejumlah temuan penelitian empiris sebelumnya. Seperti halnya kajian Yang dan Peterson (2014), Khan dan Kadir (2011), dan Dehghan et al. (2015) yang memberikan kesimpulan bahwa customer satisfaction dan perceived value berpengaruh terhadap behavioral loyalty. 


\section{Customer Satisfaction}

Customer satisfaction berkaitan dengan perasaan mereka setelah membeli barang dan jasa tertentu (Kotler \& Keller, 2016). Kepuasan merupakan fungsi dari harapan terhadap kualitas produk dan kenyataan yang mereka rasakan. Harapan terhadap produk biasanya didasarkan pada pengalaman dan informasi diperoleh sehubungan dengan keberadaan produk. Ketika kenyataan yang dirasakan pelanggan lebih rendah dibandingkan dengan harapan terhadap porduk, maka kondisi itu akan menimbulkan ketidakpuasan.

Yang dan Peterson (2014) menyatakan bahwa customer satisfaction sebagai perasaan positif secara keseluruhan tentang pelayanan yang diberikan produsen. Setelah konsumen memgkonsumsi suatu produk pastinya tidak akan terhenti hanya hingga proses konsumsi saja. Mereka pasti akan melakukan evaluasi setelah melakukan kegiatan konsumsi. Perasaan positif tersebut bisa disimpulkan sebagai perasaan konsumen yang puas setelah konsumsi yang telah dilakukan dan perasaan negatif jika konsumen merasakan ketidak puasan terhadap konsumsi produk atau jasa yang telah dilakukan.

\section{Perceived Value}

Value (nilai) dapat dilihat sebagai gap antara keuntungan atau manfaat yang dirasakan konsumen dari membeli suatu produk dengan pengorbanan yang mereka lakukan untuk melakukan pembelian tersebut. Kotler dan Keller (2016) berpendapat bahwa nilai yang ada dalam pikiran pelanggan (customer perceived value) merupakan gap antara evaluasi mereka atas semua benefit atau keuntungan yang diharapkan serta semua biaya yang mereka keluarkan dan alternatifalternatif lainnya yang ada dalam pikiran mereka.

Yang dan Peterson (2014) menyatakan bahwa customer perceived value adalah perbandingan dari hasil yang diperoleh konsumen dengan hasil produksi produsen. Konsep persamaan ini mengacu pada evaluasi konsumen terhadap apa yang adil, benar, atau pantas terhadap biaya yang dikeluarkan oleh konsumen. Jadi customer perceived value ini dilihat berdasarkan hasil evaluasi manfaat dan pengorbanan yang dilakukan terhadap sesuatu yang ditawarkan. Pengorbanan ini dapat berbentuk moneter dan non-moneter seperti waktu dan energi yang terpakai.

\section{Kerangka Pemikiran dan Hipotesis}

Mengacu pada pemaparan sebelumnya, maka keterkaitan antar variabel yang dianalisis dalam penelitian ini dapat digambarkan dalam kerangka pemikiran seperti ditunjukkan pada Gambar 1. Berdasarkan kerangka pemikiran tersebut maka dapat dimunculkan beberapa hipotesis yang diuji dalam penelitian ini.

\section{Pengaruh Perceived Value terhadap Behavioral Loyalty}

Behavioral loyalty dapat dipahami sebagai konsep yang menekankan pada runtutan pembelian, proporsi pembelian, dan probabilitas pembelian (Darsono, 2014). Behavioral loyalty lebih disebabkan karena adanya perubahan harga, lokasi yang nyaman dari seorang pembeli, dan berdasarkan evaluasi benefit (harga miring) (Neal, 2010). Perceived value dapat berpengaruh terhadap berhavioral loyalty. Hal ini dapat dijelaskan bahwa perceived value pada dasarnya merupakan nilai-nilai yang diharapkan oleh konsumen dari suatu produk. Ketika nilai yang mereka peroleh sesuai dengan harapan mereka, maka konsumen cenderung menggunakan produk tersebut secara berulangulang, sehingga membentuk behavioral loyalty. Secara empiris, adanya pengaruh perceived value terhadap behavioral loyalty dibuktikan oleh Picon-Berjoyo et al. (2016) bahwa perceived value berpengaruh positif dan signifikan terhadap behavioral loyalty. Sebelumnya penelitian Khan dan Kadir (2011) juga memberikan kesimpulan yang sama bahwa behavioral intention dalam bentuk behavioral loyalty dipengaruhi oleh perceived value.

Mengacu pada uraian tersebut, maka hipotesis pertama penelitian ini dinyatakan sebagai berikut:

$\mathbf{H}_{1}$ : Perceived value berpengaruh signifikan terhadap behavioral loyalty. 


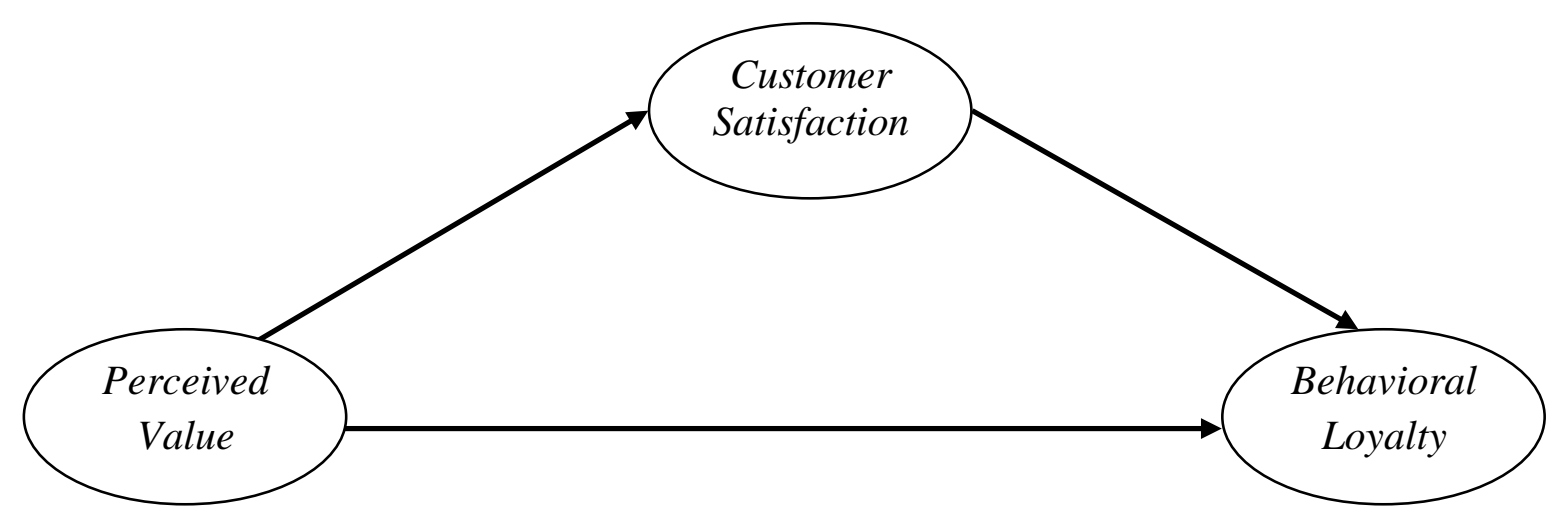

Gambar 1. Kerangka Pemikiran

\section{Pengaruh Perceived Value terhadap Customer Satisfaction}

Perceived value dapat berpengaruh terhadap customer satisfaction. Hal ini dapat dijelaskan perceived value pada dasarnya merupakan nilai-nilai yang diharapkan oleh konsumen dari suatu produk. Ketika nilai yang mereka peroleh sesuai dengan harapan mereka, maka konsumen akan cenderung puas di dalam menggunakan produk yang mereka pilih. Secara empiris, adanya pengaruh perceived value terhadap customer satisfaction ditemukan oleh Anuwichanont dan Mechinda (2016) bahwa perceived value berpengaruh positif dan signifikan terhadap customer satisfaction. Dehghan et al. (2015) juga telah membuktikan adanya pengaruh perceived value atas customer satisfaction.

Mengacu pada uraian tersebut, maka hipotesis kedua penelitian ini dinyatakan sebagai berikut:

$\mathbf{H}_{2}$ : Perceived value berpengaruh signifikan terhadap customer satisfaction.

\section{Pengaruh Customer Satisfaction terhadap Behavioral Loyalty}

Behavioral loyalty juga dapat dipengaruhi oleh customer satisfaction. Hal ini disebabkan konsumen yang puas terhadap produk tertentu akan cenderung menggunakan produk tersebut di masa yang akan datang. Sehingga semakin tinggi kepuasan yang diperoleh oleh konsumen akan semakin tinggi pula loyalitas dalam menggunakan produk itu. Dalam artin, konsumen yang menemukan kepuasan dalam menggunakan suatu produk akan memiliki perilaku loyal terhadap produk itu. Adanya keterkaitan antara behavioral loyalty dengan customer satisfaction secara empiris dibuktikan oleh Khan dan Kadir (2011) serta Dehghan et al. (2015) bahwa customer satisfaction berpengaruh positif dan signifikan terhadap loyalitas konsumen. Sebelummya Beerli et al. (2014) juga menemukan bahwa customer satisfaction berpengaruh positif terhadap behavioral loyalty.

Mengacu pada uraian tersebut, maka hipotesis ketiga dinyatakan sebagai berikut:

$\mathbf{H}_{3}$ : Customer satisfaction berpengaruh signifikan terhadap behavioral loyalty.

\section{Pengaruh Perceived Value terhadap} Behavioral Loyality Melalui Satisfaction

Pengaruh perceived value terhadap behavioral loyalty dapat terjadi secara langung maupun tidak langsung melalui customer satisfaction sebagai variabel perantara. Hal ini disebabkan, berbagai temuan empiris seperti dijelaskan sebelumnya menemukan perceived value berpengaruh terhadap customer satisfaction. Selanjutnya customer satisfaction berpengaruh terhadap behavioral loyalty. Secara empiris, pengaruh tidak langsung perceived value terhadap affective loyalty sudah dibuktikan oleh PiconBerjoyo et al. (2016) bahwa adanya customer satisfaction memediasi pengaruh perceived value terhadap behavioral loyalty. Temuan tersebut konsisten dengan temuan sebelumnya yang dilakukan oleh Lam et al. (2014), Lin et al. (2015) serta Picon et al. (2014) bahwa pengaruh perceived value terhadap behavioral loyalty dapat terjadi melalui satisfaction. 
Mengacu pada tersebut, maka hipotesis keempat dinyatakan sebagai berikut:

$\mathbf{H}_{4}$ : Perceived value berpengaruh terhadap behavioral loyalty melalui satisfaction sebagai variabel pemediasi.

\section{METODE PENELITIAN}

Penelitian dilakukan terhadap pengguna kartu kredit co-branding bank Aceh Syariah di Banda Aceh. Pengguna yang dimaksudkan dalam hal ini adalah para nasabah bank yang menggunakan kartu kredit bank tersebut. Sampel penelitian sebanyak 250 orang nasabah (pengguna kartu kredit) yang diambil secara random sampling. Pengumpulan data dalam penelitian ini dilakukan dengan cara mengedarkan kuesioner. Kuesioner tersebut berisi pernyataan yang berhubungan dengan behavioral loyalty, perceived value dan customer satisfaction.

Pernyataan-pernyataan yang diajukan dalam kuesioner dijabarkan dari indikator pengukuran masing-masing variabel. Seperti halnya behavioral loyalty yang diukur dengan menggunakan empat indikator yang terdiri dari sensitivitas pengguna terhadap biaya penggunaan kartu kredit, sensitivitas terhadap promosi kartu kredit, kekerapan penggunaan kartu kredit dan frekuensi penggunaan kartu kredit. Customer satisfaction diukur dengan menggunakan lima indikator terdiri dari kemampuan bank memenuhi kebutuhan pengguna kartu kredit, anggapan bahwa bank Aceh lebih baik dibandingkan bank lain, kemauan karyawan bank menyelesaikan komplain yang disampaikan pengguna kartu kredit, pelayanan bank sesuai harapan, anggapan bahwa bank memberikan pelayanan secara baik dan pengalaman menggunakan layanan bank. Terakhir, pengukuran variabel perceived value memakai empat indikator meliputi: kemampuan produk memuaskan kebutuhan, penilaian terhadap manfaat kartu kredit, perbandingan manfaat yang diperoleh dibandingkan dengan menggunakan produk sejenis dari bank lain, dan kemampuan bank memenuhi kebutuhan terhadap kualitas kartu kredit.

Mengingat variabel-variabel yang dioperasionalkan dalam penelitian ini adalah variabel kualitatif, diperlukan adanya proses kuantifikasi variabel tersebut sehingga dapat dianalisis dengan menggunakan peralatan statistik. Proses kunatifikasi itu dilakukan dengan memberikan skala terhadap pilihan jawaban (tingkat kesetujuan) yang disediakan untuk masing-masing pernyataan pada setiap variabel penelitian (Amri \& Surya, 2013). Skala Likert dengan skor berkisar antara 1-5. Pemberian skor berdasar tingkat kesetujuan berlaku ketentuan $1=$ sangat tidak setuju, $2=$ tidak setuju, 3 = kurang setuju, $4=$ setuju dan 5 = sangat setuju.

Sesuai dengan kerangka penelitian yang telah dijelaskan dalam Gambar 1 dapat dipahami bahwa customer satisfaction merupakan fungsi dari perceived value, dan selanjutnya behavioral loyalty merupakan fungsi dari customer satisfaction dan perceived value. Customer satisfaction dijadikan variabel pemediasi antara dan behavioral loyalty dengan perceived value. Karena itu, peralatan analisis yang diaplikasikan dalam kajian ini adalah path analysis dengan dua persamaan struktural diformulasikan sebagai berikut:

$$
\begin{aligned}
& \mathrm{CS}=\mathrm{pCSPV}+\varepsilon_{1} \\
& \mathrm{BL}=\mathrm{pBLCS}+\mathrm{pBLPV}+\varepsilon_{2}
\end{aligned}
$$

dimana:

$$
\begin{aligned}
\mathrm{PV}= & \text { Perceived value } \\
\mathrm{CS}= & \text { Customer satisfaction } \\
\mathrm{BL}= & \text { Behavioral loyalty } \\
\mathrm{pCSPV}= & \text { Koefisien jalur perceived value } \\
& \text { terhadap customer satisfaction } \\
\mathrm{pBLCS}= & \text { Koefisien jalur customer } \\
& \text { satisfaction terhadap behavioral } \\
& \text { loyalty } \\
\mathrm{pBLPV}= & \text { Koefisien jalur perceived value } \\
& \text { terhadap behavioral loyalty }
\end{aligned}
$$

Selanjutnya, pengujian signifikansi atas pengaruh antar variabel sebagai dasar penolakan ataupun penerimaan hipotesis, menggunakan peralatan statistik uji $\mathrm{t}$ pada tingkat keyakinan sebesar 95\%. Dengan menggunakan software SPSS sebagai alat bantu pengolahan data ukuran signifikansi tersebut didasarkan pada nilai sig yang dihasilkan output SPSS, dengan ketentuan jika suatu variabel eksogen tertentu memiliki 
nilai Sig. $<0.05$ berarti variabel tersebut berpengaruh signifikan. Sebaliknya jika nilai Sig. > 0.05 berarti variabel tersebut tidak berpengaruh signifikan.

Pengujian efek mediasi merujuk pada pendapat Baron dan Kenny (1986) yang berargumen bahwa pengaruh mediasi akan wujud ketika terdapat empat kriteria, yaitu: (1) Variabel eksogen mempengaruhi variabel endogen; (2) Variabel eksogen mempengaruhi variabel pemediasi; (3) Variabel pemediasi harus mempengaruhi variabel endogen; dan, (4) Full/Perfect Mediation akan wujud ketika pengaruh variabel eksogen terhadap variabel endogen secara langsung adalah tidak signifikan, tapi pengaruh tersebut signifikan ketika mengikutsertakan variabel mediasi. Selanjutnya, partial mediation terjadi ketika pengaruh variabel eksogen terhadap variabel endogen adalah signifikan, baik melibatkan variabel pemediasi maupun tanpa variabel pemediasi.

\section{HASIL ANALISIS}

\section{Analisis Pengaruh Antar Variabel}

Sebagaimana telah diuraikan, model analisis data yang digunakan dalam penelitian ini adalah analisis jalur (path analysis) yang terdiri dari dua persamaan struktural. Persamaan struktural pertama menempatkan customer satisfaction sebagai fungsi dari perceived value. Persamaan struktural kedua menempatkan behavioral loyalty sebagai fungsi dari perceived value dan customer satisfaction. Dengan menggunakan software SPSS sebagai alat bantu pengolahan data, nilai koefisien jalur suatu variabel eksogen terhadap variabel endogen tertentu dapat dilihat dari nilai standardized coefficients beta yang dihasilkan pada output SPSS.

\section{Analisis Pengaruh Perceived Value terhadap Customer Satisfaction \\ Perceived value secara positif} berpengaruh terhadap customer satisfaction dengan nilai koefisien jalur sebesar 0,625. Berdasarkan nilai koefisien tersebut secara statistik dapat diartikan bahwa pengaruh langsung (direct effect) perceived value terhadap customer satisfaction sebesar 39,06 persen. Hal ini berarti bahwa semakin baik perceived value semakin tinggi kepuasan pengguna kartu kredit. Dengan kata lain, semakin baik nilai yang dipersepsikan oleh pengguna kartu kredit sehubungan dengan keberadaan kartu kredit co-branding Bank Aceh, semakin tinggi pula kepuasan mereka dalam menggunakan kartu kredit tersebut. Adanya pengaruh positif perceived value terhadap customer satisfaction direpresentasikan dalam persamaan 3:

$$
\mathrm{CS}=0,625 \mathrm{PVCS}+0,610
$$

Persamaan 3 memperlihatkan nilai error sebesar 0,610. Angka ini diinterpretasikan bahwa sebesar 61,0 persen tingkat customer satisfaction pengguna kartu kredit adalah dipengaruhi oleh variabel-variabel lain selain perceived value. Variabel lain dimaksud adalah semua faktor yang secara teoritis dapat mempengaruhi customer satisfaction seperti pelayanan, biaya administrasi penggunaan kartu kredit dan lain sebagainya.

Analisis Pengaruh Perceived Value dan Customer Satisfaction terhadap Behavioral Loyalty

Perceived value dan customer satisfaction berpengaruh positif terhadap behavioral loyalty. Hal ini berarti semakin baik persepsi pemegang kartu kredit terhadap perceived value dan semakin tinggi kepuasan mereka dalam menggunakan kartu kredit, semakin tinggi pula behavioral loyalty. Persamaan jalur yang merepresentasikan hubungan fungsional ketiga variabel tersebut seperti ditunjukkan dalam persamaan 4 .

$\mathrm{BL}=0,500 \mathrm{BLPV}+0,685 \mathrm{BLCS}+0,680$

Berdasarkan persamaan 4 dapat dilihat bahwa koefisien jalur perceived value terhadap behavioral loyalty sebesar 0,500. Hal ini berarti bahwa pengaruh langsung perceived value terhadap behavioral loyalty sebesar 25 persen. Dengan kata lain, perceived value secara langsung (directly) mampu menjelaskan variasi yang terjadi pada affective loyalty sebesar 22,47 persen. Selanjutnya nilai koefisien jalur customer satisfaction terhadap behavioral loyalty sebesar 0,685 diartikan pengaruh customer satisfaction terhadap behavioral loyalty sebesar 46,92 persen. 


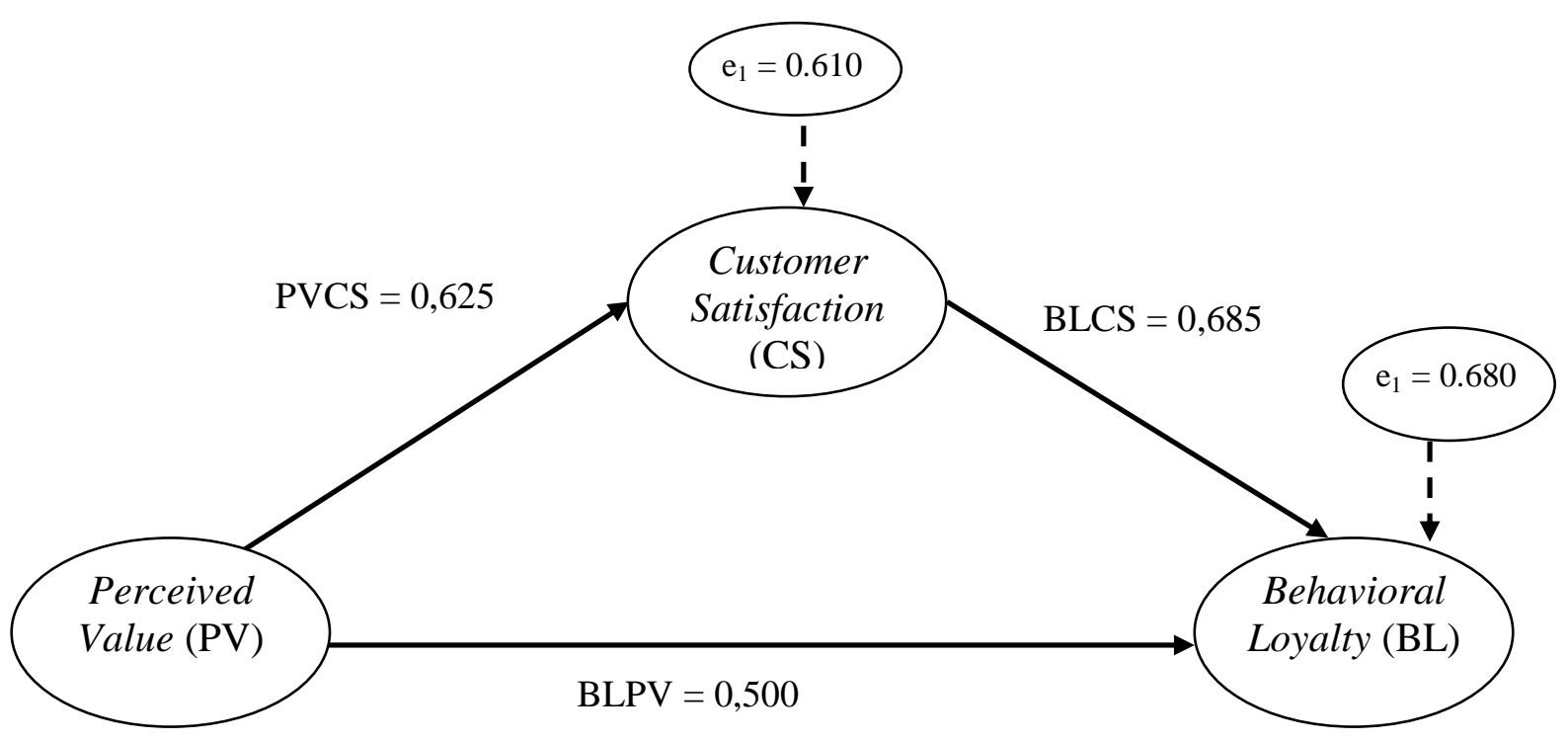

Sumber: Data Primer Diolah, 2019

\section{Gambar 2. Hasil Diagram Jalur Pengaruh}

Persamaan 4 juga memperlihatkan nilai error sebesar 0,680 dapat diartikan sebesar 68,0 persen behavioral loyalty dipengaruhi oleh faktor lain selain kedua variabel tersebut. Variabel lain dimaksud adalah seluruh faktor yang secara teoritis dan empiris sudah terbukti bisa berpengaruh terhadap behavioral loyalty selain perceived value dan customer satisfaction.

\section{Analisis Pengaruh Perceived Value terhadap Behavioral Loyalty Melalui Customer Satisfaction}

Berdasarkan kaedah analisis jalur, pengaruh tidak langsung suatu variabel terhadap variabel lainnya dicari dengan mengalikan koefisien jalur antar variabel. Sebagaimana telah dijelaskan sebelumnya, koefisien jalur perceived value terhadap customer satisfaction sebesar 0,625. Selanjutnya koefisien jalur customer satisfaction terhadap behavioral loyalty sebesar 0,685. Dengan demikian pengaruh tidak langsung perceived value terhadap behavioral loyalty melalui customer satisfaction sebesar 42,81 persen. Angka ini lebih besar apabila dibandingkan dengan pengaruh langsung perceived value terhadap behavioral loyalty sebesar 25,00 persen. Dengan demikian dapat diartikan keberadaan customer satisfaction memperkuat pengaruh perceived value terhadap behavioral loyalty pengguna kartu kredit co-branding bank Aceh.

Secara matematis, deskripsi kuantitatif berkaitan dengan direct effect dan indirect effect perceived value terrhadap behavioral loyalty melalui customer satisfaction dirangkum dalam Tabel 1.

\section{Pembuktian Hipotesis Pengaruh Langsung}

Hipotesis yang berkaitan dengan pengaruh langsung (direct effect) antar variabel terdiri dari tiga hipotesis. Penerimaan atau penolakan hipotesis mengacu pada nilai statistik yang diperoleh melalui penggunaan software SPSS sebagai alat bantu pengolahan data. Nilai statistik yang dimaksudkan adalah nilai Sig. dengan ketentuan jika nilai Sig. suatu variabel $<0,05$ berarti pengaruh langsung variabel tersebut terhadap variabel endogen tertentu adalah signifikan sehingga hipotesis terkait dapat diterima. Sebaliknya jika nilai Sig. > 0,05 berarti pengaruh langsung antar variabel itu tidak signifikan sehingga hipotesis tidak dapat diterima.

Hasil uji statistik yang memperlihatkan nilai Sig. sebagai dasar pembuktian hipotesis pengaruh langsung antar variabel ditunjukkan dalam Tabel 2. 
Tabel 1. Perbandingan Direct Effect dan Indirect Effect antar Variabel

\begin{tabular}{|c|c|c|c|}
\hline $\begin{array}{c}\text { Bentuk } \\
\text { Pengaruh }\end{array}$ & Variabel yang Dianalisis & Koefisien Jalur & $\begin{array}{c}\text { Besarnya } \\
\text { Pengaruh }(\%)\end{array}$ \\
\hline \multirow{3}{*}{$\begin{array}{l}\text { Pengaruh } \\
\text { langsung } \\
(\text { direct effect) }\end{array}$} & $\begin{array}{l}\text { Perceived value (PV) terhadap customer } \\
\text { satisfaction }(\mathrm{CS})\end{array}$ & 0,625 & 39,06 \\
\hline & $\begin{array}{l}\text { Perceived value (PV) terhadap Behavioral } \\
\text { Loyality (BL) }\end{array}$ & 0,500 & 25,0 \\
\hline & $\begin{array}{l}\text { Customer Satisfaction (CS) terhadap } \\
\text { Behavioral Loyalty (BL) }\end{array}$ & 0,685 & 46,92 \\
\hline $\begin{array}{l}\text { Pengaruh tidak } \\
\text { langsung } \\
\text { (indirect effect) }\end{array}$ & $\begin{array}{l}\text { Perceived value (PV) terhadap behavioral } \\
\text { loyalty (BL) melalui customer satisfaction } \\
\text { (CS) }\end{array}$ & 0,625 dan 0,685 & 42,81 \\
\hline
\end{tabular}

Sumber: Data Primer Diolah, 2019

Tabel 2. Pembuktian Hipotesis Pengaruh Langsung

\begin{tabular}{|c|c|c|c|c|c|}
\hline \multicolumn{3}{|c|}{ Arah Pengaruh Antar Variabel } & Koefisien Jalur & Nilai Sig. & Ket \\
\hline $\begin{array}{l}\text { Perceived } \\
\text { Value }\end{array}$ & & $\begin{array}{c}\text { Customer } \\
\text { Satisfaction }\end{array}$ & 0,625 & 0,001 & Signifikan \\
\hline $\begin{array}{l}\text { Perceived } \\
\text { Value }\end{array}$ & -- & $\begin{array}{c}\text { Behavioral } \\
\text { Loyalty }\end{array}$ & 0,500 & 0,001 & Signifikan \\
\hline $\begin{array}{c}\text { Customer } \\
\text { Satisfaction }\end{array}$ & ---------- & $\begin{array}{c}\text { Behavioral } \\
\text { Loyalty }\end{array}$ & 0,685 & 0,001 & Signifikan \\
\hline
\end{tabular}

Sumber: Data Primer Diolah, 2019

Seperti ditunjukkan dalam Tabel 2, nilai Sig. dari pengaruh langsung perceived value terhadap behavioral loyalty menunjukkan angka sebesar 0,001. Angka ini lebih kecil dari 0,05 sehingga hipotesis pertama $\left(\mathrm{H}_{1}\right)$ yang menyatakan bahwa perceived value berpengaruh terhadap behavioral loyalty adalah dapat diterima. Selanjutnya, nilai Sig. atas pengaruh langsung perceived value terhadap customer satisfaction juga lebih kecil dari 0,05 sehingga hipotesis kedua $\left(\mathrm{H}_{2}\right)$ yang menyatakan bahwa Perceived value berpengaruh terhadap customer satisfaction juga dapat diterima. Ketiga, nilai Sig. atas pengaruh langsung customer satisfaction terhadap behavioral loyalty juga lebih kecil dari 0,05 ; sehingga hipotesis ketiga $\left(\mathrm{H}_{3}\right)$ yang menyatakan bahwa customer satisfaction berpengaruh terhadap behavioral loyalty juga dapat diterima.
Adanya pengaruh positif perceived value terhadap behavioral loyalty pengguna kartu kredit mendukung temuan penelitian Picon-Berjoyo et al. (2016) yang juga menyimpulkan perceived value berpengaruh positif dan signifikan terhadap behavioral loyalty. Hasil kajian Khan dan Kadir (2011) juga memberikan kesimpulan sama bahwa behavioral intention dalam bentuk behavioral loyalty dipengaruhi perceived value.

Sebagaimana telah dijelaskan, penelitian ini juga menemukan bahwa perceived value dapat mendorong peningkatan customer satisfaction. Temuan ini sejalan dengan penelitian Anuwichanont dan Mechinda (2016) yang secara empiris menyimpulkan bahwa peningkatan customer satisfaction terkait erat dan berhubungan searah dengan perceived value. Sebelumnya, hasil kajian Dehghan et al. (2015) juga membuktikan adanya hubungan searah dan signifikan antara kedua variabel tersebut. 


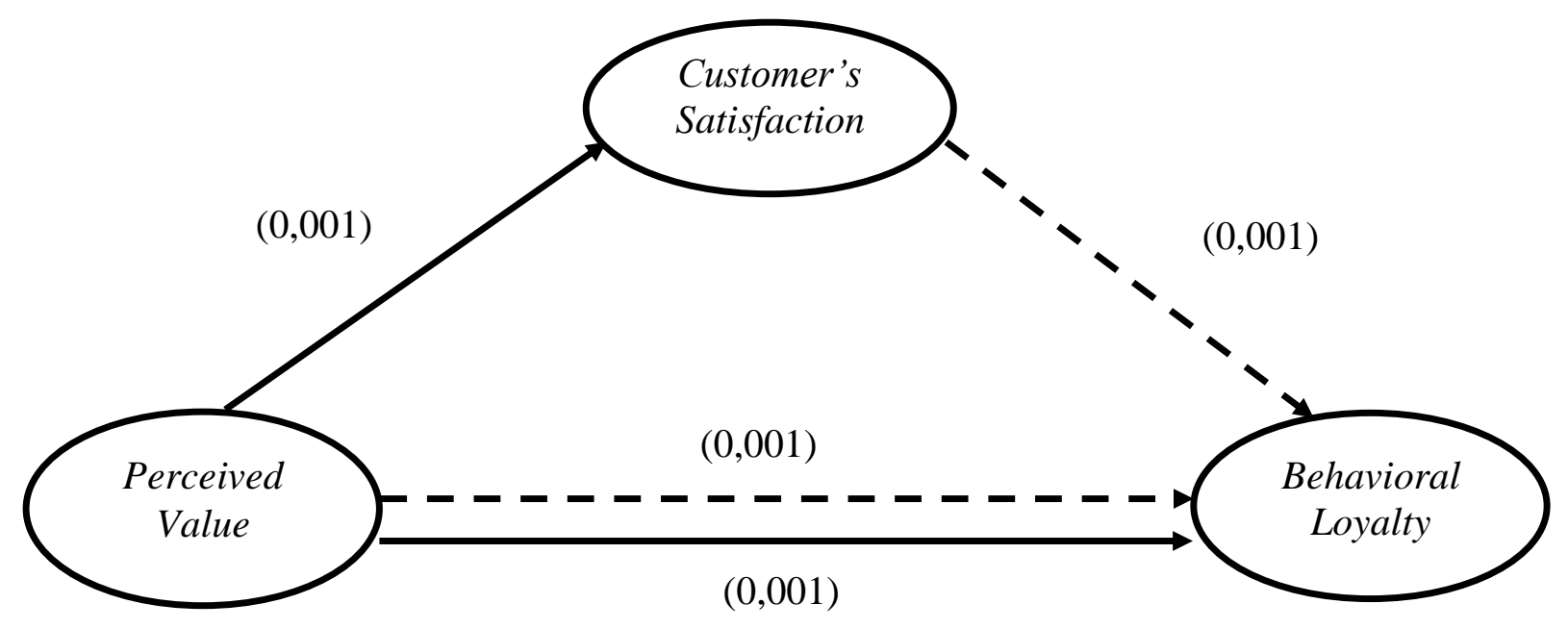

Ket.: Angka dalam kurung atau ( ) adalah nilai p-value.

Sumber: Data Primer Diolah, 2019

\section{Gambar 2. Pengujian Efek Mediasi Customer's Satisfaction Sebagai Variabel Perantara antara Perceived Value dan Behavioral Loyalty}

Hasil yang diperoleh dalam penelitian ini dimana membuktikan adanya pengaruh customer satisfaction terahadap behavioral loyalty mendukung hasil penelitian yang telah dilakukan oleh para peneliti sebelumnya seperti Khan dan Kadir (2011) serta Dehghan et al. (2015) yang dalam penelitian mereka membuktikan bahwa kepuasan merupakan faktor penentu loyalitas konsumen. Hasil kajian empiris oleh Beerli et al. (2014) juga memberikan kesimpulan yang sama, bahwa kepuasan konsumen terhadap layanan tertentu berdampak kepada pembentukan loyalitas mereka atas perusahaan pemberi layanan itu.

\section{Pembuktian Hipotesis Pengaruh Tidak Langsung}

Pengaruh perceived value terhadap behavioral loyalty tidak hanya terjadi secara langsung (direct effect), tetapi juga secara tidak langsung (indirect effect) melalui customers satisfaction yang berperan sebagai variabel intervening. Sebagaimana telah dijelaskan, pengaruh langsung (direct effect) perceived value terhadap behavioral loyalty sebesar 25,0 persen, selanjutnya pengaruh tidak langsung (indirect effect) variabel itu dengan melibatkan customers satisfaction sebagai intervening variabel terhadap kinerja pegawai sebesar 42,81 persen, adalah lebih besar bila dibandingkan dengan pengaruh langsung. Hasil ini menunjukkan customers satisfaction juga memperkuat pengaruh perceived value terhadap behavioral loyalty pemegang kartu kredit.

Pengujian efek mediasi customers satisfaction sebagai variabel perantara antara perceived value dengan behavioral loyalty juga mengacu pada pendapat Baron dan Kenny (1986), yakni dilakukan dengan regresi tiga tahap. Hasil regresi tahap pertama menunjukkan bahwa pengaruh perceived value terhadap customers satisfaction adalah signifikan dengan nilai Sig. sebesar 0,001. Selanjutnya hasil regresi tahap kedua menunjukkan bahwa perceived value terhadap behavioral loyalty juga signifikan dengan nilai Sig. sebesar 0,001. Selanjutnya hasil regresi tahap ketiga yakni menguji pengaruh perceived value dan customers satisfaction secara bersamaan terhadap behavioral loyalty juga menunjukkan bahwa kedua variabel tersebut berpengaruh signifikan dengan nilai Sig. masing-masing sebesar 0,001. Guna memudahkan analisis tentang pengujian efek mediasi dari customers satisfaction sebagai variabel perantara antara perceived value dan behavioral loyalty dapat dilihat Gambar 3.

Berdasarkan Gambar 3 dapat dilihat bahwa pengaruh perceived value terhadap customers satisfaction adalah signifikan, dan 
pengaruh customers satisfaction terhadap behavioral loyalty juga signifikan. Demikian pula halnya dengan pengaruh langsung perceived value terhadap behavioral loyalty juga signifikan. Hal ini berarti bahwa efek mediasi dari customers satisfaction sebagai variabel perantara antara perceived value dengan behavioral loyalty merupakan bentuk mediasi parsial.

Berdasarkan penjelasan tersebut, maka hipotesis $\mathrm{H}_{4}$ yang menyatakan perceived value berpengaruh terhadap behavioral loyalty melalui customer satisfaction sebagai variabel pemediasi adalah dapat diterima. Efek mediasi yang dimunculkan customer satisfaction dalam memediasi pengaruh perceived value terhadap behavioral loyalty merupakan mediasi parsial. Temuan ini mendukung hasil penelitian sebelumnya yang dilakukan oleh Picon-Berjoyo et al. (2016) bahwa pengaruh perceived value terhadap loyalitas konsumen dapat terjadi melalui kepuasan konsumen. Hal ini juga konsisten dengan hasil penelitian Lam et al. (2014), Lin et al. (2015) serta Picon et al. (2014) yang juga menyimpulkan customer satisfaction memediasi pengaruh perceived value terhadap loyalitas konsumen.

\section{KESIMPULAN}

Berdasarkan hasil-hasil penelitian yang diperoleh maka bisa dinyatakan beberapa kesimpulan Pertama, perceived value dibuktikan berpengaruh positif dan signifikan customer satisfaction dan behavioral loyality pengguna kartu kredit co-branding Bank Aceh Syariah. Semakin tinggi perceived value semakin tinggi pula customer satisfaction dan semakin tinggi kecenderungan behavioral loyalty. Sebaliknya, penurunan perceived value berdampak pada penurunan customer satisfaction yang pada gilirannya kecenderungan behavioral loyalty semakin rendah. Kedua, perceived value terbukti berpengaruh positif terhadap behavioral loyality melalui satisfaction sebagai variabel pemediasi. Pengaruh tidak langsung perceived value terhadap behavioral loyalty melalui customer satisfaction sebesar 42,81 persen lebih besar apabila dibandingkan dengan pengaruh langsung sebesar 25,00 persen. Sebagai kesimpulan akhir, dinyatakan bahwa customer satisfaction memperkuat pengaruh perceived value terhadap behavioral loyalty pengguna kartu kredit co-branding Bank Aceh. Efek yang dimunculkan oleh customer satisfaction sebagai variabel pemediasi adalah mediasi parsial.

Berdasarkan sejumlah kesimpulan itu direkomendasikan bagi pihak Manajemen Bank Aceh Syariah perlu meningkatkan perceived value dan kepuasan (satisfaction) pengguna kartu kredit co-branding bank tersebut. Peningkatan perceived value dapat dilakukan dengan cara melakukan intervensi kebijakan yang terkait dengan peningkatan kemampuan kartu kredit dalam memenuhi kebutuhan pengguna kartu kredit sehingga para pengguna tersebut dapat merasakan bahwa kartu kredit tersebut sangat bermanfaat bagi diri mereka dan lebih baik dibandingkan dengan kartu kredit bank lain. Selanjutnya, peningkatan kepuasan pengguna kartu kredit dapat dilakukan dengan cara memberikan pelayanan ekselen, termasuk melakukan respon cepat atas sekecil apapun komplain yang mereka sampaikan sehubungan dengan pelayanan kartu kredit.

Bagi peneliti yang tertarik dengan kajian yang sama di masa mendatang, diharapkan memasukkan sejumlah variabel lainnya selain perceived value dan customer satisfaction untuk memprediksi sikap behavioral loyalty pengguna kartu kredit co-branding Bank Aceh. Sehingga kajian terhadap determinan loyalitas pengguna kartu kredit tersebut dapat diketahui secara lebih detail dan dapat dijadikan masukan bagi pengambil kebijakan produk dan pemasaran kartu kredit bank tersebut.

\section{UCAPAN TERIMA KASIH}

Kami sebagai peneliti mengucapkan terima kasih yang sebesar-besarnya kepada Ditjen Penguatan Riset dan Pengembangan Kementerian Riset, Teknologi dan Pendidikan Tinggi sebagai penyandang dana penelitian pada skema Penelitian Dosen Pemula (PDP) tahun 2019, dan tidak lupa pula kepada LP2M Sekolah Tinggi Ilmu Ekonomi (STIE) 
Sabang, Banda Aceh yang telah ikut menfasilitasi kelancaran proses penelitian ini.

\section{DAFTAR PUSTAKA}

Amri, K. dan Surya, J. 2013. Kajian Perilaku Mahasiswa Dalam Menggunakan Internet Dengan Pendekatan Technology Acceptance Model (TAM). Jurnal Penelitian Pos dan Informatika. Vol. 3, No. 1, hal. 67-80.

Amri, K., Qurratul'aini, I., dan Julianty. 2018. Preferensi Nasabah Memilih Produk Pembiayaan Bank Aceh Syariah di Kota Banda Aceh. Jurnal Samudra Ekonomi dan Bisnis. Vol. 9, No. 1, hal. 31-41.

Amri, K. dan Nazamuddin. 2018. Is There Causality Relationship Between Economic Growth And Income Inequality? Panel Data Evidence from Indonesia. Eurasian Journal of Economics and Finance. Vol. 6, No. 2, hal. 8-20.

Anuwichanont, J. dan Mechinda, P. 2016. The Impact of Perceived Value on Spa Loyalty and Its Moderating Effect of Destination Equity. Journal of Business \& Economics Research. Vol. 7, No. 12, hal. 75-90.

Asy'ari, A.H. 2014. Pengaruh Value dan Trust Terhadap Behavioral Loyalty (Studi Pada Konsumen Sepeda Motor Honda di Banjarmasin). Kindai. Vol. 10, No. 1, hal. 1-12.

Baron, R.M. dan Kenny, D.A. 1986. The Moderator-Mediator Variable Distinction in Social Psychological Research: Conceptual, Strategic, and Statistical Considerations. Journal of Personality and Social Psychology. Vol. 51, No. 6, hal. 1173-1182.

Beerli, A., Martín, J. dan Quintana, A. 2014. A Model Of Customer Loyalty In The Retail Banking Market. European Journal of Marketing. Vol. 38, hal. 253-275.

Darsono, L.I. 2014. Loyalty \& Disloyalty: Sebuah Pandangan Komprehensif Dalam Analisis Loyalitas Pelanggan.
Jurnal Kinerja. Vol. 8, No. 2, hal. 163173.

Dehghan, N.A., Alizadeh, H. dan MirzaeiAlamouti, S. 2015. Exploring the Customer Perceived Values As Antecedent Of Purchase Behavior. Serbian Journal of Management. Vol. 10, No. 2, hal. 173-188.

Giddens, N. dan Hofmann, A. 2012. Brand Loyalty. (online) http://www. extension.iastate.edu/agdm/wholefarm. diakses 11 Februari 2019.

Khan, N. dan Kadir, S.L.S.A. 2011. The Impact Of Perceived Value Dimension On Satisfaction And Behavior Intention: Young-Adult Consumers In Banking Industry. African Journal of Business Management. Vol. 5, No. 11, hal. 4087-4099.

Kotler, P. dan Keller, K.L. 2016. Manajemen Pemasaran. Edisi Kedua Belas Jilid 1. Jakarta: PT. Indeks.

Lam, S.Y., Shankar, V., Erramilli, M.K. dan Murthy, B. 2014. Customer Value, Satisfaction, Loyalty, And Switching Costs: An Illustration From A Businessto Business Service Context. Journal of the Academy of Marketing Science. Vol. 32, No. 3, hal. 293-311.

Lin, C.H., Sher, P.J. dan Shih, H.Y. 2015. Past Progress And Future Directions In Conceptualizing Customer Perceived Value. International Journal of Service Industry Management. Vol. 16, No. 4, hal. 318-336.

Oliver, R.L. 2017. Satisfaction: A Behavioral Perspective on The Consumer. New York: The McGrawHill Companies. Inc.

Picon, A., Castro, I. dan Roldan, J.L. 2014. The Relationship Between Satisfaction And Loyalty: A Mediator Analysis. Journal of Business Research. Vol. 67, No. 5, hal. 746-751.

Picon-Berjoyo, A., Ruiz-Moreno, C. dan Castro, I. 2016. A Mediating And Multigroup Analysis Of Customer Loyalty. European Management Journal. Vol. 34, No. 6, hal. 1-13. 
Schiffman, L.G. dan Kanuk L.L. 2014. Consumer Behavior. Seventh Edition. New Jersey: Prentice Hall International.

Shanmugam, A., Savarimuthu, M.T. dan Wen, T.C. 2014. Factors Affecting Malaysian Behavioral Intention To Use Mobile Banking With Mediating Effects Of Attitude. Academic Research
International. Vol. 5, No. 2, hal. 236253.

Yang, Z. dan Petterson, R.T. 2014. Customer Perceived Value, Satisfaction, And Loyalty: The Role Of Switching Costs. Psychology and Marketing. Vol. 21, No. 10, hal. 799-822. 